\title{
Decarbonization of Maritime Transport: Analysis of External Costs
}

\author{
Ernest Czermański, Barbara Pawłowska, Aneta Oniszczuk-Jastrząbek and \\ Giuseppe T. Cirella*
}

Faculty of Economics, University of Gdansk, Sopot, Poland

OPEN ACCESS

Edited by:

Simona Liguori,

Worcester Polytechnic Institute,

United States

Reviewed by:

Ahmet Arisoy,

Istanbul Technical University, Turkey

Fehmi Akgun,

TUBITAK Marmara Research Centre

Energy Institute, Turkey

*Correspondence:

Giuseppe T. Cirella

gt.cirella@ug.edu.pl

Specialty section:

This article was submitted to Advanced Fossil Fuel Technologies,

a section of the journal

Frontiers in Energy Research

Received: 14 November 2019

Accepted: 14 February 2020

Published: 27 February 2020

Citation:

Czermański E, Pawłowska B,

Oniszczuk-Jastrząbek A and Cirella GT (2020) Decarbonization of Maritime

Transport: Analysis of External Costs.

Front. Energy Res. 8:28.

doi: 10.3389/fenrg.2020.00028
For centuries Europe's transport has been a catalyst for economic development. At present, it facilitates exchange among European Union (EU) Member States and much of the rest of the world. Maritime transport forms the main axis of international exchange, carrying $\sim 90 \%$ of total traded tonnage. In doing so, it bears responsibility for $2.5 \%$ of worldwide greenhouse gas emissions. The efforts to reduce negative environmental impact of transport activity is centered on better modal integration of the common transport system, sustainability, green technologies in the transport sector, resource efficiency, and carbon emissions reduction. The International Maritime Organization has tasked its members to achieve a 70\% reduction in $\mathrm{CO}_{2}$ emissions by 2050 or, if possible, to eliminate them altogether. From a business end, it is possible to apply a variety of technologies to ensure zero-emissions or, at the least, a dramatic reduction of emissions in the shipping sector. The aim of this paper is to evaluate the strategic approach to the decarbonization process based on EU strategic documents and low-emission and zero-emission technologies, used and developed, in maritime transport. An estimation of external costs incurred by maritime transport will allow for the assessment of benefits resulting from the application of technologies and alternative fuels proposed in the solutions. On the basis of the obtained results from the external cost valuation it will be possible to estimate the potential for decarbonization in maritime transport.

Keywords: shipping and the environment, emission reductions, cost valuation, external costs theory, IMO, EU

\section{INTRODUCTION}

A certain number of important environmental precedents have been recorded over the last two decades; unfortunately, the vast majority of them are far from positive (Hebbert and Jankovic, 2013; Dewan et al., 2018; Rony et al., 2019). In 2016, according to the World Economic Forum (WEF), it was the first year in which an environmental danger, specifically the failure to mitigate and adapt to climate change, ranked above weapons of mass destruction, water shortage, and energy resource prices (WEF, 2018). As can be seen, environmental concerns have been a priority for the WEF in recent years (Obersteiner et al., 2018; Simpson and Jewitt, 2019). Because of this, state parties to the Paris Agreement committed to reducing their greenhouse gas (GHG) emissions, with the aim of limiting global warming to well-below $2^{\circ} \mathrm{C}$ above pre-industrial levels, and to pursue efforts to keeping the increase down to $1.5^{\circ} \mathrm{C}$ (Karmalkar and Bradley, 2017; Nikulin et al., 2018). Despite international shipping being excluded from the Paris Agreement, the International Maritime Organization (IMO) is developing its own strategy to reduce ship-derived GHGs. The IMO argues a need for common activities and efforts to mitigate environmental burdens, as set out by its MEPC.304(72) Resolution, 13 April 2018, three sustainability-oriented goals for the entire 
maritime shipping industry: (1) reduce carbon compound (i.e., oxides and dioxides) emissions from new ships through the implementation of successive phases of the Energy Efficiency Design Index (EEDI), (2) reduce carbon compound emissions in shipping by at least $40 \%$ by 2030 , with efforts to achieve $70 \%$ reduction by 2050 (i.e., from the baseline year of 2008), and (3) reduce GHG emissions in maritime shipping by at least $50 \%$ by 2050 with simultaneous action aimed at their complete elimination (Psaraftis, 2019). Lastly, an additional goal is to move toward zero-emissivity in maritime shipping (Psaraftis, 2016). The IMO has also decided that in order to support the drive toward emission targets, the energy efficiency of ships should increase by $40 \%$ by 2030 (i.e., compared to 2008 levels) and by $50-70 \%$ by 2050 .

Maritime shipping is currently responsible for $<3 \%$ of total manmade $\mathrm{CO}_{2}$ emissions. Forecasting predicts that by 2050 this proportion will grow from 50 to $250 \%$ with the business-asusual model (i.e., with no action taken). The Kyoto Protocol climate target, set a worldwide cap of $1.5-2.0^{\circ} \mathrm{C}$ on global warming (UNFCCC, 1997, 2008), calling for a reduction in $\mathrm{CO}_{2}$ emissions by $50-85 \%$ for the whole economy. Currently available technologies allow reductions of up to $75 \%$ (Bouman et al., 2017). Supplementary Table 1 presents data on $\mathrm{CO}_{2}$ emissions from maritime shipping in the period from 2007 to 2015 and its share in overall emission levels. It can be deduced that total shipping $\mathrm{CO}_{2}$ emissions, after a downturn between 2008 and 2010, increased from 910 million tons to 932 million tons (i.e., $+2.4 \%$ ) from 2013 to 2015 . It is still below the 2008 peak, but according to forecasts international shipping emissions may increase, exceeding the 2007 level. In 2015, global shipping accounted for approximately $2.6 \%$ of global $\mathrm{CO}_{2}$ emissions. The majority (i.e., $87 \%$ ) of shipping $\mathrm{CO}_{2}$ emissions is attributable to international shipping activity (Jalkanen et al., 2016; Johansson et al., 2017; Russo et al., 2020). Domestic shipping accounted for about $9 \%$ of total shipping $\mathrm{CO}_{2}$ emissions and fishing accounted for $\sim 4 \%$ in 2015 . Examining the ship fleet structure, it can be observed that $55 \%$ of that figure (i.e., over a half) was generated by container ships, bulk carriers, and oil tankers. It is well-known that the level of ship emissions depends on such factors as fuel consumption, engineering design as well as engine operation and maintenance. Also, in the case of individual ship designs and fuels, the amount of emissions depends on the way in which the engines are operated (EDGAR, 2017). Therefore, a single voyage is divided into four stages according to vessel operation modes, namely: free sailing, maneuvering, anchoring, and berthing. According the International Council on Clean Transportation report, free sailing accounts for the most $\mathrm{CO}_{2}$ emissions across all ship classes, while maneuvering accounts for the least (Jiang et al., 2012; Olmer et al., 2017). The IMO has tasked its members to reduce $\mathrm{CO}_{2}$ emissions to $70 \%$ by 2050 or, if possible, to completely eliminate them. This means that ship-owning enterprises will have to immediately act to reduce ship-derived $\mathrm{CO}_{2}$ emissions, while also striving to eliminate emissions. Hence, there arises a question as to the maritime shipping sector's potential for reducing $\mathrm{CO}_{2}$ emissions, both in quantitative and monetary terms [i.e., reducing external costs (Antheaume, 2004; Wang et al., 2017)]. As such, this paper aims at evaluating approaches of the decarbonization process based on European Union (EU) strategic documents and low-emission and zero-emission technologies, used and developed, in maritime transport in the context of $\mathrm{CO}_{2}$ emission reduction.

\section{METHOD}

To achieve the shipping sector's potential for decarbonization, it is necessary to calculate the external costs of $\mathrm{CO}_{2}$ reductions. Full cost accounting in terms of external costs theory is applied (Antheaume, 2004; Mizutani et al., 2011; Frischmann and Marciano, 2015; Wang et al., 2017). For this purpose, tabularized datasets have been put together to show basic quantitative and qualitative data on global shipping [i.e., fleet size, deadweight tonnage (DWT) (Supplementary Table 2), gross registered tonnage, main engine power output, and power generator output for commercial vessels (Supplementary Table 3)]. The resulting figures are then compared with average fuel consumption data at main engine load where maximum continuous rating (MCR) $=0.85$. To simplify matters, average figures for speed and corresponding fuel consumption correspond with engine type. Consideration has been given to three principal marine fuels, including: heavy fuel oil (HFO), marine gas oil (MGO), and liquefied natural gas (LNG) (Elgohary et al., 2015; Thomson et al., 2015; Hansson et al., 2019).

The resulting data have been inputted into an external cost calculator developed in the "Ecobonus" project (MAE, 2018). The calculator is used to estimate the external costs of maritime shipping compared to transport by road at specified distances per cargo unit expressed in linear meters. For the purpose of this research, this parameter has been cross-referenced to deadweight tonnage. The input data in the calculator included variable voyage speed, non-linear function of fuel consumption relative to speed, normative $\mathrm{CO}_{2}$ emission indexes for selected fuel types, normative external costs in maritime shipping (i.e., $\left.€ 187.00 / \mathrm{t}-\mathrm{CO}_{2}\right)$, and normative external costs in transport by road (i.e., $0.10 € / \mathrm{vkm}$ noise, $0.21 € / \mathrm{vkm}$ accidents, and 0.19 $€ /$ vkm congestion). $\mathrm{CO}_{2}$ emission costs have been calculated for different variants at the variable average speed of shipping traffic, starting from $15 \mathrm{kn}$ through 17,19 , and $21 \mathrm{kn}$ as the most representative velocities for present-day maritime shipping. The authors believe the calculator has a serious flaw whereby it adopts an excessive fuel consumption index for $217 \mathrm{~g} / \mathrm{kWh}$ energy efficiency. To correct for this unrealistic rate, the value has been replaced by $180 \mathrm{~g} / \mathrm{kWh}$ (i.e., 17\% lower). The original figure overstated the external costs as a result of overestimated fuel consumption. Another defect is in its limited list of fuel types to choose from.

\section{RESULTS}

\section{Strategic Approach to Low- and Zero-Emission Technology}

Basic guidelines for contemporary development of Europe's transport policy have been set out in the "Strategy for intelligent and sustainable development favoring social inclusion," adopted 
in March 2010, and the "White Paper: A Plan for establishing a harmonized European transport area-striving to achieve a competitive and energy-saving transport system" (Pawłowska, 2013; Wojewódzka-Król, 2017). Focusing primarily on the regulations and documents relating to shipping emissions, it is established, the advancement of sustainable development of maritime transport correlates with $\mathrm{CO}_{2}$ emissions. This aspect has been dealt with in the International Convention on the Prevention of Pollution of the Sea by Ships-MARPOL 73/78. The problem of reducing ship-derived $\mathrm{CO}_{2}$ emissions has been discussed in Appendix VI to the MARPOL Convention. As such, if the amount of $\mathrm{CO}_{2}$ emissions is considered the direct product of fuel consumption and, by extension, the type of technology and engine used in a ship, the pertinent regulations refer to energy efficiency of ship engines (Bijlsma, 2008; Yuan et al., 2017). As of 2013 (i.e., according to Appendix VI amendment to the MARPOL Convention), it is obligatory to determine the EEDI for newly designed ships with more than 400 registered tonnage (RT) as well as any type of drive, except for LNG, and the Energy Efficiency Operational Indicator (EEOI) for ships already in service. Introduced provisions, establishing the obligation to implement the Efficiency Plan Energy Management, were established in 2011 (Kotowska, 2014). These indicators are a tool-based energy efficiency assessment of ships regardless of age and will in the long-term determine allowable fuel consumption norms, whereby the EEDI is a theoretical value reflecting future efficiency and the EEOI is a practical benchmark for $\mathrm{CO}_{2}$ emissions measured under specific travel and service conditions for a given ship.

There is no agreement as to the effectiveness of the EEDI procedures. Research by Ančić and Šestan (2015) elucidate the reduction of $\mathrm{CO}_{2}$ according to these procedures will be easier than expected, meaning that the size of the reduction may exceed forecasts. Other research, questions the potential for further reduction of $\mathrm{CO}_{2}$ emissions, specifically in LNG-powered ships, as vessels now under construction, equipped with this drive, will be propelled by a dual fuel engine that will fully comply with the EEDI limits (Attah and Bucknall, 2015). Indeed, Shi (2016) goes further by stating implementation of the EEDI alone, and consequently other ship service parameter indicators, will not suffice and make it necessary to market the practice (i.e., bring it in-line with shipping practice) and technical capacity, to a larger extent, required by the IMO resolution. The IMO's future objectives have been specified in the published report "Initial strategy on reduction of GHG emissions from ships" (IMO, 2018). It is worth noting, the IMO Resolution MEPC.304(72), introducing the EEDI as an instrument for reducing GHG emissions in international shipping, was the first legislative act in international law following the ratification of the Kyoto Protocol (Bickel et al., 2005). Hence, it is legitimate to assume that the shipping sector is serious about sustainable development goals and willing to commit itself to reducing GHG emissions.

\section{Estimation of External Costs in EU Transport}

In the last decade, public concerns regarding the environmental impacts of maritime transport have been increasing. This is due to the fact that, despite a better environmental performance, its overall impacts will be outweighed by the expected increase in the volume of ship movements (Turvani et al., 2009). External costs of transport refer to the difference between social costs and private costs of transport. Those costs are defined as the costs which arise when the social or economic activities of one group of persons have an impact on another group and when that impact is not fully accounted, or compensated, for by the first group (Bickel et al., 2005). The reason for this is lack of market incentive for transport users to take external costs into account when making a transport decision. External costs have been a key issue in transport research since 1995. In Europe, this trend is in line with the political willingness to internalize externalities in transport pricing policies. Total external costs of transport for the EU Member States (MSs) in 2016 were estimated in the updated handbook on the external costs of transport (Supplementary Figure 1; European Commission, 2019a).

The total external costs for road, rail, inland waterway transport (IWT), aviation, and maritime (i.e., excluding
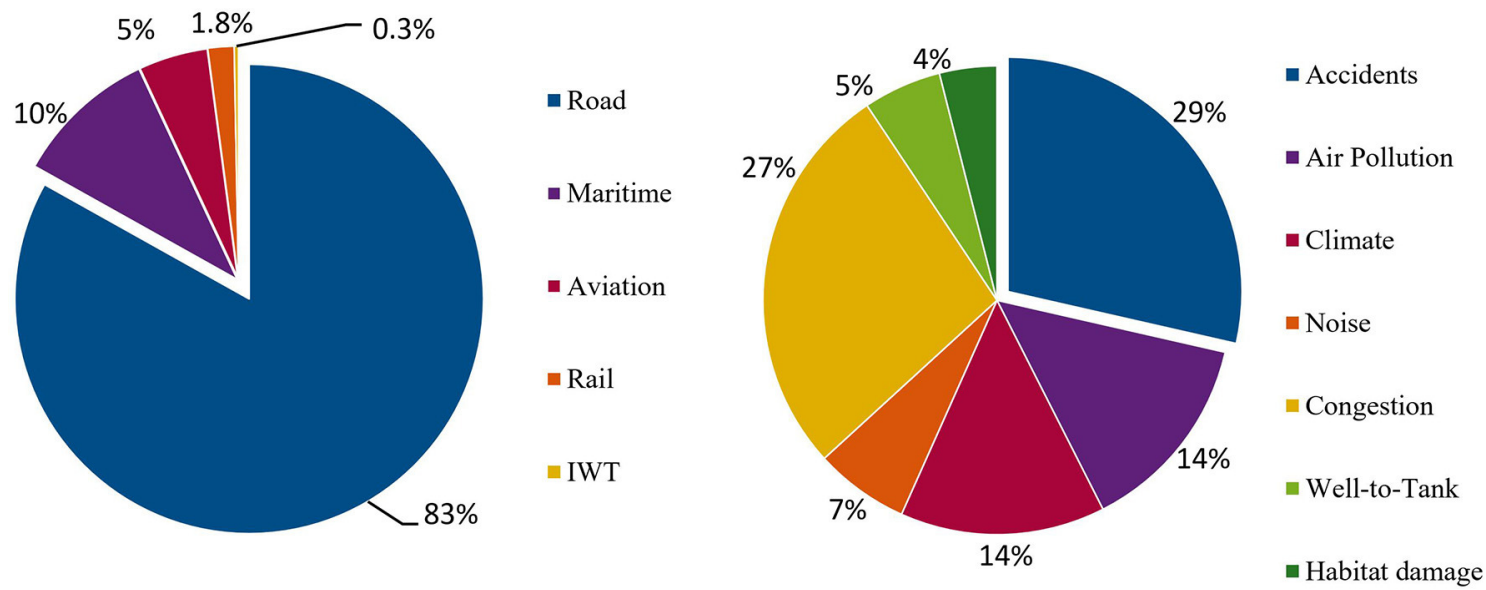

FIGURE 1 | Share of mode and cost categories in total external costs of transport for MSs in 2016, adopted from the European Commission (2019b). 
congestion costs as they are not calculated for all modes) amount to $€ 71$ billion, which corresponds to $4.8 \%$ of the total gross domestic product in the MSs. For aviation and maritime transport, a detailed calculation of the external costs has only been done for a set of selected airports and sea ports. Maritime shipping (i.e., $50 \%$ allocated to origin and $50 \%$ to destination) was worth $€ 44$ billion for all traffic to-and-from 34 selected EU ports with the indicative estimate for all traffic to-and-from all EU ports at $€ 98$ billion. Figure 1 illustrates the share of mode and cost categories for total external costs of transport for MSs in 2016.

Road transport is the predominant mode that incurs by far the most external costs (i.e., $83 \%$ of the total costs). Maritime transport accounts for $10 \%$, aviation for $5 \%$, rail transport for $1.8 \%$, and IWT for $0.3 \%$ of the costs. Total external transport costs can be further broken down with $69 \%$ dedicated to passenger transport and $31 \%$ to freight (i.e., including light commercial vehicles). The most important cost category is accident costs equaling $29 \%$ of the total costs, followed by congestion (i.e., 27\%). Climate change and air pollution costs both contribute to $14 \%$, noise costs to $7 \%$, and habitat damage to $4 \%$ of the total costs. The most important cost categories for maritime transport are climate change and air pollution. Total climate costs for maritime shipping have been estimated to be $€ 24$ billion-based on transport performance for consistency with the other transport modes and cost categories. It is worth

TABLE 1 | Specification of selected technologies and solutions exploiting the potential of ships for reducing $\mathrm{CO}_{2}$ emissions, adopted from Czermański (2019).

\begin{tabular}{|c|c|c|c|c|c|c|c|c|c|c|c|}
\hline \multirow[t]{2}{*}{ Area } & \multirow[t]{2}{*}{ Measurement } & \multirow[t]{2}{*}{ Solution } & \multicolumn{3}{|c|}{$\mathrm{CO}_{2}$ reduction potential [\%] } & \multicolumn{3}{|c|}{ Investments costs [\%] } & \multicolumn{3}{|c|}{$\mathrm{CO}_{2}$ reduction cost [USD/1t] } \\
\hline & & & Min. & Average & Max. & Min. & Average & Max. & Min. & Average & Max. \\
\hline \multirow[t]{7}{*}{ Hull design } & Vessel size & $\begin{array}{l}\text { Economy of scale, improved } \\
\text { capacity utilization }\end{array}$ & 4.00 & 18.00 & 83.00 & 0.00 & 0.00 & 0.00 & -159.00 & -159.00 & -159.00 \\
\hline & Hull shape & $\begin{array}{l}\text { Dimensions and form } \\
\text { optimization }\end{array}$ & 2.00 & 14.50 & 30.00 & 2.50 & 10.00 & 25.00 & 12.00 & -54.00 & -36.00 \\
\hline & Light materials & $\begin{array}{l}\text { High strength steel, } \\
\text { composites }\end{array}$ & 0.10 & 5.30 & 22.00 & 1.00 & 10.00 & 50.00 & 1036.00 & 86.00 & 131.00 \\
\hline & Air lubrication & Hull air cavity lubrication & 1.00 & 5.30 & 15.00 & 5.00 & 7.50 & 10.00 & 744.00 & 31.00 & -77.00 \\
\hline & $\begin{array}{l}\text { Resistance reduction } \\
\text { devices }\end{array}$ & $\begin{array}{l}\text { Other devices/retrofit to } \\
\text { reduce resistance }\end{array}$ & 0.00 & 8.00 & 10.00 & 0.00 & 2.00 & 3.00 & 0.00 & -50.00 & -70.00 \\
\hline & Ballast water reduction & $\begin{array}{l}\text { Change in design to reduce } \\
\text { size of ballast }\end{array}$ & 1.00 & 2.50 & 10.00 & 0.25 & 0.50 & 2.50 & -106.00 & -112.00 & -106.00 \\
\hline & Hull coating & Distinct types of coating & 2.00 & 6.00 & 45.00 & 10.00 & 20.00 & 40.00 & 451.00 & 256.00 & -31.00 \\
\hline \multirow{5}{*}{$\begin{array}{l}\text { Power and } \\
\text { propulsion } \\
\text { system }\end{array}$} & $\begin{array}{l}\text { Hybrid } \\
\text { power/propulsion }\end{array}$ & $\begin{array}{l}\text { Hybrid electric auxiliary power } \\
\text { and propulsion }\end{array}$ & 0.00 & -2.50 & -5.00 & - & - & - & - & - & - \\
\hline & $\begin{array}{l}\text { Power } \\
\text { system/machinery }\end{array}$ & & 1.00 & 5.80 & 25.00 & 0.50 & 1.00 & 5.00 & -77.00 & -118.00 & -121.00 \\
\hline & $\begin{array}{l}\text { Propulsion efficiency } \\
\text { devices }\end{array}$ & & 1.00 & 8.00 & 20.00 & 0.50 & 2.50 & 5.00 & -77.00 & -98.00 & -106.00 \\
\hline & Waste heat recovery & Recuperation & 0.10 & 1.20 & 3.00 & 0.10 & 0.10 & 0.10 & 100.00 & -47.00 & -56.00 \\
\hline & $\begin{array}{l}\text { On board power } \\
\text { demand }\end{array}$ & $\begin{array}{l}\text { On Board or auxiliary power } \\
\text { demand }\end{array}$ & 25.00 & 70.00 & 84.00 & 10.00 & 10.00 & 10.00 & -88.00 & -118.00 & -121.00 \\
\hline \multirow[t]{2}{*}{ Alternative fuels } & Biofuels & Methanol, ethanol & 5.00 & 20.00 & 30.00 & - & 30.00 & - & 100.00 & -47.00 & -56.00 \\
\hline & LNG & LNG & 0.00 & -2.00 & -3.00 & 0.00 & 0.00 & 0.00 & - & - & - \\
\hline \multirow{4}{*}{$\begin{array}{l}\text { Alternative } \\
\text { energy sources }\end{array}$} & Wind power & Kites, sails, wings & 1.00 & 12.60 & 50.00 & 0.50 & 5.00 & 25.00 & -77.00 & -89.00 & -77.00 \\
\hline & Fuel cells & $\mathrm{H}_{2}$ & 2.00 & 6.50 & 20.00 & 0.00 & 0.00 & 0.00 & $>1,000$ & $>1,000$ & $>1,000$ \\
\hline & Cold ironing & Electricity from shore & 3.00 & 5.30 & 10.00 & 0.25 & 0.25 & 0.25 & -125.00 & -130.00 & -132.00 \\
\hline & Sola power & Solar panels on deck & 0.20 & 4.00 & 12.00 & 5.00 & 5.00 & 5.00 & 2794.00 & 158.00 & 12.00 \\
\hline \multirow[t]{4}{*}{ Operation } & Speed optimization & $\begin{array}{l}\text { Operational Speed, reduced } \\
\text { speed }\end{array}$ & 1.00 & 19.60 & 60.00 & 0.00 & 0.00 & 0.00 & -160.00 & -160.00 & -160.00 \\
\hline & Capacity utilization & $\begin{array}{l}\text { At vessel and fleet level (fleet } \\
\text { management) }\end{array}$ & 5.00 & 23.50 & 50.00 & 0.00 & 0.00 & 0.00 & -159.00 & -159.00 & -159.00 \\
\hline & Voyage optimization & $\begin{array}{l}\text { Advanced weather routing, } \\
\text { route planning and voyage } \\
\text { execution }\end{array}$ & 0.10 & 7.30 & 48.00 & 0.00 & 0.00 & 0.00 & -159.00 & -159.00 & -159.00 \\
\hline & $\begin{array}{l}\text { Other operational } \\
\text { measures }\end{array}$ & $\begin{array}{l}\text { Trim/draft optimization, energy } \\
\text { management, optimized } \\
\text { maintenance }\end{array}$ & 1.00 & 3.70 & 10.00 & 0.00 & 0.00 & 0.00 & -159.00 & -159.00 & -159.00 \\
\hline
\end{tabular}


mentioning that for climate change costs, the marginal costs are the same as the average costs. This is because the average and marginal climate emissions per $\mathrm{km}$ of a vehicle are equal. This implies that an additional kilogram of $\mathrm{CO}_{2}$ emitted leads to the same social (i.e., external) costs as the average kilogram of $\mathrm{CO}_{2}$ emitted, since the $\mathrm{CO}_{2}$ is distributed in the whole atmosphere. This cost category contributed $0.2 €$-cent/tkm, while air pollution costs amounted to $0.4 €-$ cent/tkm (European Court of Auditors, 2013; European Commission, 2019a).

\section{Description of Low- to Zero-Emission Technology in Maritime Transport}

Maritime transport takes advantage of a variety of optimizing, and frequently innovative, solutions aimed mainly to reduce fuel consumption by the ship engine (Rehmatulla and Smith, 2015). In that sense, the obvious direction for ship owner community efforts is consistent with the sustainable development goal relating to reduction of ship-derived emissions. The literature points out various methods of classification and analyses of areas in which emissions from ships can be reduced, using-for example-emission-reducing technology as the classifying criterion. Accordingly, Seddiek et al. (2013) have distinguished three areas for possible reductions: ship engine, fuel quality, and fuel usage. Another classification applies emissions-reducing technology as its basic criterion (Bouman et al., 2017), classing the following five stages: (1) design, (2) modernization of existing drive systems, (3) retrofitting, (4) alternative fuels, or adding alternative power sources for on-board devices, and (5) time in commercial service. The most widespread emissions-reducing technologies can be segmented into the following areas: hull design, power and propulsion system, alternative fuels, alternative energy sources, and operation (Table 1).

The measures that are being developed and applied to reduce ship-derived emissions primarily rely on the quality of fuel used. The resulting reductions are possible due to technical progress which is, on the one hand, elicited by ship owners themselves pushing for more fuel-efficient solutions. On the other hand, standards, and regulations in international law are becoming noticeably more restrictive, setting increasingly rigorous limits on emissions from ships during the sea voyage and port stoppage. This emission-limiting process can be divided into four stages (Table 2). Ship owners can quickly transition through these stages by, first, placing news ship-building orders and second, modernize the existing fleet. A detailed look at the process includes:

1. Exhaust gas treatment-all kinds of technologies bringing emission levels from traditional marine fuels into compliance with the applicable limits; note, these do not eliminate exhaust gases.

2. Cleaner fuels-technologies allowing for the use of cleaner fossil fuels, such as LNG and MGO, for compliance with the applicable emissions limits. LNG results in a $15 \%$ saving on $\mathrm{CO}_{2}$ emissions, while MGO-being a more energy-rich fuel than $\mathrm{HFO}-$ leads to $1.3 \%$ increase in emissions.
TABLE 2 | Four stages of effective $\mathrm{CO}_{2}$ reduction, adopted from Untiedt (2018).

\begin{tabular}{llll}
\hline Stage & & Technology & $\mathbf{C O}_{\mathbf{2}}$ \\
\hline 1 & Purifying & $\begin{array}{l}\text { Scrubber + selective catalytic } \\
\text { reduction (SCR) }\end{array}$ & No change \\
2 & Cleaner fuels & MGO, LNG & $-15 \%$ \\
3 & E-fuels & Hybrid: LNG or methanol or & $-80 \%$ \\
4 & MGO converted to electricity & $-100 \%$ \\
& e/ $/ \mathrm{H}_{2}$ & $\begin{array}{l}\text { Liquid hydrogen }\left(\mathrm{LH}_{2}\right) \text { or pure } \\
\text { electric ship }\end{array}$ & \\
\hline
\end{tabular}

3. E-fuels-cutting-edge technologies using fuels for on-board power generation and allowing ships to be driven by electrical energy incorporates all kinds of renewable energy sources.

4. e/ $\mathrm{H}_{2}$-one of the only two technologies nowadays (i.e., except renewable energy sources on electrically powered ships) allows for zero-emissions shipping by using renewable energy sources to generate power for hydrogen production or to charge the ship's batteries.

From these technologies, there are no currently available fossil fuel technologies complying with the requirements on pollutant emissions, including $\mathrm{CO}_{2}$, as stipulated in the MARPOL Convention regulations. Therefore, stage one should continue to be improved via technical development and further low- to zero-emissivity technologies streamlined.

\section{Assessment Potential of Decarbonization in Maritime Shipping}

The calculation carried out produced a final estimate of external costs of $\mathrm{CO}_{2}$ emissions as an indicator of the potential for future reductions in maritime shipping compared to the existing state. The calculations were made using the "Ecobonus" (MAE, 2018) project calculator based on figures for emission levels from road transport as an alternative to maritime transport. This calculator was designed to promote the EU's Motorways of the Sea (MoS) program. Because of this, it is necessary to consider not only the quantitative reductions of external costs expressed in USD, but also the previously calculated volumes of $\mathrm{CO}_{2}$ emissions from the global shipping fleet. At the beginning, the primary database data from IHS (2019) were used to determine the consumption of marine fuels in the individual fleet types. This was followed by a conversion of their use to $\mathrm{CO}_{2}$ emissions. The results are presented in Table 3.

The total emissions from the global fleet according to the existing fuel structure used in global shipping stood at 2.167 billion tons of $\mathrm{CO}_{2}$ and-interestingly-is equal to the amount of emissions that would be obtained with the exclusive use of HFO. Therefore, the $2 \%$ contributed by LNG, which is lower on $\mathrm{CO}_{2}$ emissions, neutralizes the $26 \%$ share produced by MGO, which has a much higher $\mathrm{CO}_{2}$ emissivity. Assuming that the entire fleet would transition to MGO which is cleaner fuel in terms of $\mathrm{SO}_{\mathrm{x}}$ and $\mathrm{NO}_{\mathrm{x}}$ emissions (Seddiek and Elgohary, 2014), we would receive 2.23 billion tons of $\mathrm{CO}_{2}$ emissions, which represents a slight increase compared to 
TABLE 3 | Estimated fuel consumption and $\mathrm{CO}_{2}$ emissions in global shipping in 2018.

\begin{tabular}{|c|c|c|c|c|c|}
\hline \multirow[t]{2}{*}{ Fleet group } & \multirow{2}{*}{$\begin{array}{c}\text { Marine fuel } \\
\text { use } \\
\text { (million } t \text { ) }\end{array}$} & \multicolumn{4}{|c|}{$\mathrm{CO}_{2}$ emission for } \\
\hline & & HFO & MGO & LNG & $\begin{array}{c}\text { Current fuel use } \\
\text { structure }^{\dagger}\end{array}$ \\
\hline Bulk carriers & 173.0 & 538,7 & 554.6 & 475.8 & 538.7 \\
\hline $\begin{array}{l}\text { Liquid cargo } \\
\text { ships }\end{array}$ & 224.0 & 697.5 & 718.1 & 616.0 & 697.5 \\
\hline $\begin{array}{l}\text { General cargo } \\
\text { and cruise ships }\end{array}$ & 299.0 & 931.1 & 958.6 & 822.2 & 931.1 \\
\hline Total & 696.0 & 2167.3 & 2231.3 & 1914.0 & 2167.3 \\
\hline
\end{tabular}

${ }^{\dagger}$ Fuel percentages sourced from Olmer et al. (2017): 72\% for HFO, 26\% for MGO, and $2 \%$ for $L N G$.

the existing circumstance. For a complete transition to LNG, the new figure for $\mathrm{CO}_{2}$ emissions would equal 1.914 billion tons, which is just $12.7 \%$ less compared to the current HFObased variant.

The calculator "Ecobonus" (MAE, 2018) compares direct road door-to-door externalities with the MoS alternative considering specific vessel technology, operating profile, port call, and port access impact. By adopting the output by the calculator for the external costs of 1 ton of $\mathrm{CO}_{2}$ emissions (i.e., $\mathrm{HFO}=159.10$ $\mathrm{USD}$; $\mathrm{MGO}=153.44 \mathrm{USD}, \mathrm{LNG}=112.40 \mathrm{USD}$; for various combinations: LNG + SCR 112.40 USD, HFO + scrubber + $\mathrm{SCR}=162,28 \mathrm{USD}$, and MGO + SCR $=153.44 \mathrm{USD})$, it was possible to determine the total external costs of $\mathrm{CO}_{2}$ emissions in global shipping. For HFO, these were 348.91 billion USD, for MGO 337.57 billion USD and for LNG 214.37 billion USD which represents approximately $61.4 \%$ of the same cost for HFO. Model adjustment equated to 0.96 , with the model error ranging from USD 8.41 to USD 11.90 per unit of emissions. The stated values were determined for $15 \mathrm{kn}$ average traffic speed. Analogous calculations were produced for higher speeds (i.e., 17, 19, and $21 \mathrm{kn}$ ) in order to emphasize the upward trend in the external costs of ships with no exhaust cleaning technologies-showed a fixed level.

\section{DISCUSSION}

The analyses have proven a number of important points; however, they should be interpreted with caution. First, the final external cost estimates of 1 ton of $\mathrm{CO}_{2}$ emissions are based on a calculation of externalities in land transport as no methods for calculating emissions in maritime transport have been developed. Consequently, more experience of how external costs accumulate in maritime shipping is necessary for a more realistic estimate. Second, it is also a mistake to adopt the estimated fuel consumption structure of 2017 for 2018 data (i.e., since no current data is available). Additionally, the structure itself includes only three main types of marine fuel with the exclusion of electrical, hybrid, and methanol-powered drives. Also, future planned use of liquefied hydrogen would significantly alter the projections. As such, worldwide statistical illustrate of actual consumption of these fuels for each ship type will need to be closely monitored and updated (i.e., as data become available).

Finally, fuel consumption data from 2018 was based only on engine power output and fuel consumption characteristics per power output at MCR $=0.85$. The value of this indicator can vary depending on the global state of the economy which, in turn, determines the speed of ships (i.e., speeds are higher when demand for shipping is elevated). Despite these shortcomings, the following conclusions can be decisively formulated: (1) there are existing technically and economically viable technologies for ship drives, allowing for the reductions in emissions to generate different implementation costs to the ship owner; (2) the entire maritime sector should be steered toward a transition to cleaner fuels; (3) an intermediate stage should be a transition to LNG to generate fewer external costs, regardless of any exhaust treatment installations (i.e., to reduce $\mathrm{NO}_{\mathrm{x}}$ emissions); (4) a theoretical assumption of the global fleet's complete transition to LNG will allow for the reduction of up to $38.5 \%$ of external costs, even though reductions in $\mathrm{CO}_{2}$ emissions will reach only $11.7 \%$ and, best-case scenario, 15\%; and (5) LNG does not ensure compliance with future $\mathrm{CO}_{2}$ emissions limits for longer than 11 years, which calls for urgent action to develop alternative fuel technologies, especially in regards to renewable fuels. Finally, future research into the decarbonization of maritime transport will require political will, instituted at the global level. Parallel research into potential political side effects should also be carefully considered since much of the processes discussed are complex and fragmented between environmentally-friendly action and economic progress.

\section{DATA AVAILABILITY STATEMENT}

The collected data can made available from the corresponding author on reasonable request.

\section{AUTHOR CONTRIBUTIONS}

EC, BP, and AO-J contributed conception and design of the study. $\mathrm{EC}$ and AO-J organized the dataset and statistical analysis. EC wrote the first draft of the manuscript. EC, BP, AO-J, and GC wrote sections of the manuscript. All authors contributed to manuscript revision, read, and approved the submitted version.

\section{ACKNOWLEDGMENTS}

Extended gratitude and appreciation are directed to Rector Prof. Dr. Hab. Jerzy Piotr Gwizdała as well as colleagues from the Faculty of Economics, University of Gdansk, Gdansk, Poland. Additional acknowledgments are aimed at international maritime colleagues for collaborative help in piecing together and developing this research.

\section{SUPPLEMENTARY MATERIAL}

The Supplementary Material for this article can be found online at: https://www.frontiersin.org/articles/10.3389/fenrg. 2020.00028/full\#supplementary-material 


\section{REFERENCES}

Ančić, I., and Šestan, A. (2015). Influence of the required EEDI reduction factor on the CO2 emission from bulk carriers. Energy Policy 84, 107-116. doi: 10.1016/j.enpol.2015.04.031

Antheaume, N. (2004). Valuing external costs-from theory to practice: implications for full cost environmental accounting. Eur. Account. Rev. 13, 443-464. doi: $10.1080 / 0963818042000216802$

Attah, E., and Bucknall, R. (2015). An analysis of the energy efficiency of LNG ships powering options using the EEDI. Ocean Eng. 110, 62-74. doi: 10.1016/j.oceaneng.2015.09.040

Bickel, P., Friedrich, R., Droste-Franke, B., Bachmann, T. M., Greßmann, A., Rabl, A., et al. (2005). ExternE: Externalities of Energy, Methodology 2005 Update. Luxembourg: Office for Official Publications of the European Communities.

Bijlsma, S. J. (2008). Minimal time route computation for ships with pre-specified voyage fuel consumption. J. Navig. 61, 723-733. doi: $10.1017 /$ S037346330800492X

Bouman, E. A., Lindstad, E., Rialland, A. I., and Strømman, A. H. (2017). Stateof-the-art technologies, measures, and potential for reducing GHG emissions from shipping - a review. Transp. Res. Part D Transp. Environ. 52, 408-421. doi: 10.1016/j.trd.2017.03.022

Czermański, E. (2019). Morska Żegluga Kontenerowa a Zrównoważony Rozwój Transportu. Gdansk: Wyd. ITiHM Uniwersytet Gdański.

Dewan, M. H., Yaakob, O., and Suzana, A. (2018). Barriers for adoption of energy efficiency operational measures in shipping industry. WMU J. Marit. Aff. 17, 169-193. doi: 10.1007/s13437-018-0138-3

EDGAR (2017). Emissions Database for Global Atmospheric Researcher: CO2 Time Series 1990-2015 per Region and Country. Available online at: http://edgar.jrc. ec.europa.eu/overview.php?v=CO2ts1990-2015 (accessed July 27, 2019).

Elgohary, M. M., Seddiek, I. S., and Salem, A. M. (2015). Overview of alternative fuels with emphasis on the potential of liquefied natural gas as future marine fuel. Proc. Inst. Mech. Eng. Part M J. Eng. Marit. Environ. 229, 365-375. doi: $10.1177 / 1475090214522778$

European Commission (2019a). Handbook on the External Costs of Transport. Available online at: https://ec.europa.eu/transport/sites/transport/files/studies/ internalisation-handbook-isbn-978-92-79-96917-1.pdf (accessed July 31, 2019).

European Commission (2019b). State of Play of Internalisation in the European Transport. Available online at: https://ec.europa.eu/transport/sites/transport/ files/studies/internalisation-state- of-play-isbn-978-92-76-01413-3.pdf (accessed July 31, 2019).

European Court of Auditors (2013). Have the Marco Polo Programmes Been Effective in Shifting Traffic Off the Road?. Luxembourg: Special Report No. 3, European Court of Auditors.

Frischmann, B. M., and Marciano, A. (2015). Understanding the problem of social cost. J. Institutional Econ. 11, 329-352. doi: 10.1017/S17441374140 00472

Hansson, J., Månsson, S., Brynolf, S., and Grahn, M. (2019). Alternative marine fuels: prospects based on multi-criteria decision analysis involving Swedish stakeholders. Biomass Bioenergy 126, 159-173. doi: 10.1016/j.biombioe.2019.05.008

Hebbert, M., and Jankovic, V. (2013). Cities and climate change: the precedents and why they matter. Urban Stud. 50, 1332-1347. doi: 10.1177/0042098013480970

IHS (2019). Online Database. IHS Marit. Portal. Available online at: https:// maritime.ihs.com/EntitlementPortal/Home/Index (accessed June 30, 2019).

IMO (2018). Resolution MEPC.304(72) (Adopted on 13 April 2018): Initial IMO Strategy on Reduction of GHG Emissions from Ships. London: International Maritime Organization.

Jalkanen, J.-P., Johansson, L., and Kukkonen, J. (2016). A comprehensive inventory of ship traffic exhaust emissions in the European sea areas in 2011. Atmos. Chem. Phys. 16, 71-84. doi: 10.5194/acp-16-71-2016

Jiang, L., Kronbak, J., and Christensen, L. P. (2012). External Costs of Maritime Shipping: A Voyage-Based Methodology, 1-18. Available online at: https://pdfs. semanticscholar.org/7999/e00b4d6a3aaead4acc004b5ed86bc97e2cc4.pdf?_ $\mathrm{ga}=2.24206137 .2059823459 .1573654584-1102016446.1573654584 \quad$ (accessed October 13, 2019)
Johansson, L., Jalkanen, J.-P., and Kukkonen, J. (2017). Global assessment of shipping emissions in 2015 on a high spatial and temporal resolution. Atmos. Environ. 167, 403-415. doi: 10.1016/j.atmosenv.2017.08.042

Karmalkar, A. V., and Bradley, R. S. (2017). Consequences of global warming of $1.5^{\circ} \mathrm{C}$ and $2^{\circ} \mathrm{C}$ for regional temperature and precipitation changes in the contiguous United States. PLOS ONE. 12:e0168697. doi: 10.1371/journal.pone.0168697

Kotowska, I. (2014). Żegluga Morska Bliskiego Zasięgu w Świetle Idei Zrównoważonego Rozwoju Transportu. Szczecin: Wydaw. Nauk. Akademii Morskiej.

MAE (2018). About Med Atlantic Ecobonus. Available online at: http://mae-project. eu/about (accessed July 29, 2019).

Mizutani, F., Suzuki, Y., and Sakai, H. (2011). Estimation of social costs of transport in Japan. Urban Stud. 48, 3537-3559. doi: 10.1177/0042098011399597

Nikulin, G., Lennard, C., Dosio, A., Kjellström, E., Chen, Y., Hänsler, A., et al. (2018). The effects of 1.5 and 2 degrees of global warming on Africa in the CORDEX ensemble. Environ. Res. Lett. 13:065003. doi: 10.1088/1748-9326/aablb1

Obersteiner, M., Bednar, J., Wagner, F., Gasser, T., Ciais, P., Forsell, N., et al. (2018). How to spend a dwindling greenhouse gas budget. Nat. Clim. Chang. 8, 7-10. doi: 10.1038/s41558-017-0045-1

Olmer, N., Comer, B., Roy, B., Mao, X., and Rutherford, D. (2017). Greenhouse Gas Emissions from Global Shipping, 2013-2015. Washington, DC: International Council on Clean Transportation.

Pawłowska, B. (2013). Zrównoważony Rozwój Transportu na Tle Współczesnych Procesów Społeczno-Gospodarczych. Gdansk: Wyd. UG.

Psaraftis, H. N. (2016). Green Transportation Logistics. ed. H. N. Psaraftis. Cham: Springer International Publishing. doi: 10.1007/978-3-319-17175-3

Psaraftis, H. N. (2019). Decarbonization of maritime transport: to be or not to be? Marit. Econ. Logist. 21, 353-371. doi: 10.1057/s41278-018-0098-8

Rehmatulla, N., and Smith, T. (2015). Barriers to energy efficiency in shipping: a triangulated approach to investigate the principal agent problem. Energy Policy 84, 44-57. doi: 10.1016/j.enpol.2015.04.019

Rony, A. H., Kitada, M., Dalaklis, D., Ölçer, A. I., and Ballini, F. (2019). Exploring the new policy framework of environmental performance management for shipping: a pilot study. WMU J. Marit. Aff. 18, 1-24. doi: 10.1007/s13437-019-00165-z

Russo, M. A., Relvas, H., Gama, C., Lopes, M., Borrego, C., Rodrigues, V., et al. (2020). Estimating emissions from tourism activities. Atmos. Environ. 220. doi: 10.1016/j.atmosenv.2019.117048

Seddiek, I. S., and Elgohary, M. M. (2014). Eco-friendly selection of ship emissions reduction strategies with emphasis on SOx and NOx emissions. Int. J. Nav. Archit. Ocean Eng. 6, 737-748. doi: 10.2478/IJNAOE-2013-0209

Seddiek, I. S., Mosleh, M. A., and Banawan, A. A. (2013). Fuel saving and emissions cut through shore-side power concept for high-speed crafts at the red sea in Egypt. J. Mar. Sci. Appl. 12, 463-472. doi: 10.1007/s11804-013$1218-6$

Shi, Y. (2016). Reducing greenhouse gas emissions from international shipping: Is it time to consider market-based measures? Mar. Policy 64, 123-134. doi: 10.1016/j.marpol.2015.11.013

Simpson, G. B., and Jewitt, G. P. W. (2019). The development of the water-energyfood nexus as a framework for achieving resource security: a review. Front. Environ. Sci. 7:8. doi: 10.3389/fenvs.2019.00008

Thomson, H., Corbett, J. J., and Winebrake, J. J. (2015). Natural gas as a marine fuel. Energy Policy 87, 153-167. doi: 10.1016/j.enpol.2015.08.027

Turvani, M., Perujo, A., Massarutto, A., Mannino, I., Paccagnan, V., Miola, A., et al. (2009). External Costs of Transportation Case Study: Maritime Transport. OPOCE. Available online at: https://ec.europa.eu/jrc/en/publication/eurscientific-and-technical-research-reports/external-costs-transportation-casestudy-maritime-transport (accessed November 13, 2019).

UNFCCC (1997). Kyoto Protocol to the United Nations Framework Convention on Climate Change. Available online at: https://unfccc.int/kyoto_protocol (accessed July 31, 2019).

UNFCCC (2008). Kyoto Protocol Reference Manual on Accounting of Emissions and Assigned Amount. Kyoto: United Nations Framework Convention on Climate Change Available online at: https://unfccc.int/resource/docs/publications/08_ unfccc_kp_ref_manual.pdf 
Untiedt, G. (2018). "Next generation cruise ships: sustainability with LNG, methanol and fuel cell solutions," in NOW-Symposium Zero Emission Shipping (Hamburg: NOW-Symposium Zero Emission Shipping).

Wang, Z., Tsai, Z., Fu, J., Zhao, L., and Yang, L. (2017). Internalization of negative external cost of green logistics and incentive mechanism. Adv. Mech. Eng. 9:168781401771542. doi: 10.1177/16878140177 15420

WEF (2018). Global Risks Report 2016. Available online at: http://wef.ch/risks2016 (accessed July 25, 2019).

Wojewódzka-Król, K. (2017). "Dilemmas of the sustainable development of transport infrastructure in Poland," in Zeszyty Naukowe Uniwersytetu Gdanskiego: Ekonomika Transportu i Logistyka, 63, 93-102.

Yuan, Y., Li, Z., Malekian, R., and Yan, X. (2017). Analysis of the operational ship energy efficiency considering navigation environmental impacts. J. Mar. Eng. Technol. 16, 150-159. doi: 10.1080/20464177.2017.13 07716

Conflict of Interest: The authors declare that the research was conducted in the absence of any commercial or financial relationships that could be construed as a potential conflict of interest.

Copyright (C) 2020 Czermański, Pawłowska, Oniszczuk-Jastrząbek and Cirella. This is an open-access article distributed under the terms of the Creative Commons Attribution License (CC BY). The use, distribution or reproduction in other forums is permitted, provided the original author(s) and the copyright owner(s) are credited and that the original publication in this journal is cited, in accordance with accepted academic practice. No use, distribution or reproduction is permitted which does not comply with these terms. 